\title{
Article \\ Experimental Models to Study Skin Wound Healing with a Focus on Angiogenesis
}

\author{
Eberhard Grambow ${ }^{1, * \mathbb{D}}$, Heiko Sorg ${ }^{2,3}$, Christian G. G. Sorg ${ }^{4}$ and Daniel Strüder ${ }^{5}$ \\ 1 Department of General, Visceral, Thoracic, Vascular and Transplantation Surgery, \\ Rostock University Medical Center, 18057 Rostock, Germany \\ 2 Department of Health, University of Witten/Herdecke, Alfred-Herrhausen-Str. 50, 58455 Witten, Germany; \\ heiko.sorg@t-online.de \\ 3 Department of Plastic, Reconstructive, Aesthetic and Hand Surgery, Klinikum Westfalen, \\ Am Knappschaftskrankenhaus 1, 44309 Dortmund, Germany \\ 4 Chair of Management and Innovation in Health Care, Department of Management and Entrepreneurship, \\ Faculty of Management, Economics and Society, Witten/Herdecke University, Alfred-Herrhausen-Straße 50, \\ 58455 Witten, Germany; christian.sorg@uni-wh.de \\ 5 Department of Oto-Rhino-Laryngology, Head and Neck Surgery “Otto Körner", \\ Rostock University Medical Center, 18057 Rostock, Germany; daniel.strueder@med.uni-rostock.de \\ * Correspondence: eberhard.grambow@med.uni-rostock.de
}

check for

updates

Citation: Grambow, E.; Sorg, H.; Sorg, C.G.G.; Strüder, D.

Experimental Models to Study Skin

Wound Healing with a Focus on

Angiogenesis. Med. Sci. 2021, 9, 55. https://doi.org/10.3390/ medsci 9030055

Received: 21 June 2021

Accepted: 18 August 2021

Published: 25 August 2021

Publisher's Note: MDPI stays neutral with regard to jurisdictional claims in published maps and institutional affiliations.

Copyright: (C) 2021 by the authors. Licensee MDPI, Basel, Switzerland. This article is an open access article distributed under the terms and conditions of the Creative Commons Attribution (CC BY) license (https:// creativecommons.org/licenses/by/ $4.0 /)$.
Abstract: A large number of models are now available for the investigation of skin wound healing. These can be used to study the processes that take place in a phase-specific manner under both physiological and pathological conditions. Most models focus on wound closure, which is a crucial parameter for wound healing. However, vascular supply plays an equally important role and corresponding models for selective or parallel investigation of microcirculation regeneration and angiogenesis are also described. In this review article, we therefore focus on the different levels of investigation of skin wound healing (in vivo to in virtuo) and the investigation of angiogenesis and its parameters.

Keywords: dorsal skin fold chamber; chorion-allantois model; rabbit; mouse; ear; in virtuo; in silico

\section{Introduction}

Sufficient blood supply plays one of the most important roles in the entire body for the maintenance of body homeostasis. To guarantee nutrition and metabolism for tissue and organ function, a vascular system with an appropriate circulation is required. Especially in the wound healing of the skin, the restoration of the blood supply over the entire period is an indispensable process. This can be seen impressively in both the acute and chronic forms of wound healing.

Whereas in acute wound healing, e.g., after a cut, the vascular system already initiates wound healing from the very beginning by vasoconstriction and activation of the coagulation cascade, one recognizes the importance of the vascular system in the absence or limited function in wound healing disorders. The processes of neovascularization and angiogenesis in skin repair are highly complex and must be subdivided, because each phase of wound healing requires contradictory processes [1]. To investigate wound healing, models are needed that can reflect the physiological or pathological conditions in humans. In this context, in vivo, in vitro/ex vivo, and in virtuo/in silico models can be distinguished [2,3]. In recent years, many new in vitro and in virtuo models have been developed, which consider the pathogenesis of wound healing and the identification of new drugs or biomarkers (because of the goal to reduce animal experiments). Since a wide variety of wound healing models have been described, this article focuses on the processes involved in vascularization and microcirculation in the skin and presents new results, models and methods for their analysis. It is the aim of this review to summarize established 
and new in vivo and in vitro models for wound healing, to illustrate their advantages and disadvantages and to describe the key points of implementation of the respective models.

\section{In Vivo Models}

In vivo models still represent the gold standard in the investigation of physiological and pathological processes. They ensure the analysis of relevant questions in a whole organism and thus all possible influencing factors and their effects on the expected outcome.

Animal models are widely used in the preclinical phase of the development of new pharmaceutical agents for both risk assessment and pharmacokinetic studies. In this context, however, the transferability of results from animals to humans must be questioned critically, and thus the use of animals as experimental subjects in general. In the case of in vivo models, various models have been described for large and small animals and for humans, but over the last 20 years mouse, human, rat and pig models have prevailed [4]. Other species, such as rabbits, goats, hamsters, frogs, or zebrafish are scarcely used as wound healing models [4]. The transferability of data from animals to humans always plays an important role in this context. The anatomical differences must be considered and are summarized in Table 1.

Table 1. Skin characteristics of different species according to wound healing models (modified from [5]).

\begin{tabular}{|c|c|c|c|c|}
\hline Parameter & Human & Mouse & Rat & Porcine (Domestic) \\
\hline Skin thickness & $2-3 \mathrm{~mm}$ & Very thin $(0.4-1.0 \mathrm{~mm})$ & $1.0-2.0 \mathrm{~mm}$ & $1.5-2.0 \mathrm{~mm}$ \\
\hline Epidermis thickness & $\begin{array}{c}\text { Relatively thick } \\
70(50-120) \mu \mathrm{m}, \\
2.67 \text { layers }\end{array}$ & $\begin{array}{l}\text { 9.4-13.3 } \mu \mathrm{m}, 1.75 \text { layers } \\
\text { female inc. thickness }\end{array}$ & $\begin{array}{c}21.7 \mu \mathrm{m}, \\
1.83 \text { layers }\end{array}$ & $\begin{array}{c}\text { Relatively thick } \\
\text { 52-100 } \mu \mathrm{m}, 3.94 \text { layers }\end{array}$ \\
\hline $\begin{array}{l}\text { Stratum corneum } \\
\text { thickness }\end{array}$ & $10-12.05 \mu \mathrm{m}$ & $2.9 \mu \mathrm{m}$ & $5 \mu \mathrm{m}$ & $12.28 \mu \mathrm{m}$ \\
\hline Dermal thickness & $2.28 \mathrm{~mm}$ & $\begin{array}{c}170-500 \mu \mathrm{m} \text {, male inc. } \\
\text { thickness }\end{array}$ & $\mathrm{N} / \mathrm{A}$ & $1.5-1.8 \mathrm{~mm}$ \\
\hline Fixed skin & Yes & No & No & Yes \\
\hline Hair coat & Sparse, 11 hairs $/ \mathrm{cm}^{2}$ & Thick, 658 hairs $/ \mathrm{cm}^{2}$ & Thick, 289 hairs $/ \mathrm{cm}^{2}$ & $\begin{array}{c}\text { Sparse, } 11-31 \\
\text { hairs } / \mathrm{cm}^{2}\end{array}$ \\
\hline $\begin{array}{l}\text { Substantial Melanin } \\
\text { is }\end{array}$ & Yes & $\begin{array}{l}\text { Only in darkly } \\
\text { pigmented strains }\end{array}$ & $\begin{array}{l}\text { Only in darkly } \\
\text { pigmented strains }\end{array}$ & No for \\
\hline Eccrine sweat glands & Yes & Yes, paws & Yes, paws & $\begin{array}{l}\text { Yes, snout, lips, carpal } \\
\text { gland only }\end{array}$ \\
\hline $\begin{array}{l}\text { Apocrine sweat } \\
\text { glands }\end{array}$ & Yes & $\mathrm{N} / \mathrm{A}$ & $\mathrm{N} / \mathrm{A}$ & Yes \\
\hline $\begin{array}{l}\text { Epithelial cellular } \\
\text { turnover rate }\end{array}$ & $28 \mathrm{~d}$ & $\mathrm{~N} / \mathrm{A}$ & $\mathrm{N} / \mathrm{A}$ & $28 \mathrm{~d}$ \\
\hline $\begin{array}{c}\text { Dermal } \\
\text { vascularization }\end{array}$ & $\mathrm{N} / \mathrm{A}$ & $\mathrm{N} / \mathrm{A}$ & $\mathrm{N} / \mathrm{A}$ & Less than human \\
\hline $\begin{array}{l}\text { Skin blood flow rate } \\
(\mathrm{mL} / \mathrm{min} / 100 \mathrm{~g})\end{array}$ & 3.12 & 20.6 & 9.6 & 3.0 \\
\hline $\mathrm{pH}$ of skin & 5 & $\mathrm{~N} / \mathrm{A}$ & $\mathrm{N} / \mathrm{A}$ & $6-7$ \\
\hline $\begin{array}{l}\text { Primary Wound } \\
\text { Healing Pattern }\end{array}$ & Re-epithelialization & Contraction & Contraction & Re-epithelialization \\
\hline $\begin{array}{l}\text { Wound Healing Time } \\
\text { course }\end{array}$ & $7-14 \mathrm{~d}$ or longer & $\begin{array}{l}\text { Closes through } \\
\text { contraction, }<7 \mathrm{~d}\end{array}$ & $\begin{array}{l}\text { Closes through } \\
\text { contraction, }<7 \mathrm{~d}\end{array}$ & $12-14 \mathrm{~d}$ or longer \\
\hline
\end{tabular}

Regarding in vivo models of angiogenesis in skin wound healing, it is necessary to further distinguish between the possible direct studies, such as intravital fluorescence microscopy (IVM) [5-7], and the indirect methods, (histological or biomechanical analyses of tissue samples from an in vivo skin wound model) [8]. While direct methods often use the mouse or hamster dorsal skin fold chamber model to visualize healing processes [5,9-12], tissue samples from any of the described models can be used in indirect methods. However, the use of an in vivo model, besides the investigation in an overall system, also offers the possibility of combining different analytical approaches. 
The investigation possibilities can therefore be divided between the direct in vivo results, laboratory analyses, preservation of tissue, organ and blood samples for further in vitro cell assay use or, as mentioned above, specific histological and immunohistochemical analyses [3]. Especially in the analysis's context of skin wound healing, our research group could establish a new model. This mouse dorsal skinfold chamber model enables skin wound healing analysis in the sense of wound closure by epithelialization and examination of the inflammatory response or angiogenesis $[5,8,13]$. In this model, it was found that the restoration of blood vessels in the regenerating skin wound follows a very specific pattern [5]. Initially, a circle of vessels of irregular diameter and blood flow velocities develops parallel to the wound edge. The circle contracts towards the center of the wound, forming radial blood vessels at the edge, with significantly more regular blood flow and vessel diameters. However, after completion of wound healing with complete epithelialization, this pattern disappears and the reticular structure of physiological skin develops $[1,5]$. The primary mechanism of wound closure in the mouse is wound contraction (Table 1). Another advantage of the described method is that this mechanism is counteracted by the stretching of the skin in the dorsal skin fold chamber and, thus, it is a real re-epithelialization, like the human mechanism [5].

In this context, the use of human patients or volunteers is also discussed. Microdosing is currently a new research field in which application of active substances in small quantities is performed. The small dose is supposed to avoid health issues. Highly sensitive methods are then used to measure active ingredients during absorption, distribution, metabolism, and excretion. However, positive or curative effects on humans cannot be determined by micro-dosing. In addition to the ethical problems of human experiments, the active substances tested in micro-dosing must first be developed. In this respect, microdosing is a first step from animal testing to human application and is primarily used in pharmacological studies so far $[14,15]$.

This review focusses on four of the most established in vivo models for skin wound healing and vascular assessment, i.e. the dorsal skinfold chamber model, the splinted full thickness model, the hairless mouse auricle model and the chorion-allantois membrane assay (Table 2).

\subsection{The Dorsal Skinfold Chamber Model}

The chamber model was first described in 1924 by Sandison in the ear of rabbits and was later converted to the dorsal skin of mice [16-18] (Figure 1). Since then, microcirculation and tissue engineering research have frequently used the mouse dorsal skinfold chamber [19]. Microcirculatory studies focused on inflammation [20,21], thrombogenesis [22,23], thrombolysis [24,25], angiogenesis of tumors [26-28], endometriosis [29,30], biomaterials [31,32] and flap perfusion [33,34]. The number of studies using the dorsal skinfold chamber model for different approaches proves the dorsal skinfold chamber to be one of the most important in vivo models for repetitive microcirculation assessment. 
Table 2. Schematic illustration and overview on important advantages and limitations of established in vivo models for angiogenesis in wound healing.

\begin{tabular}{|c|c|c|c|c|c|c|}
\hline & \multirow{2}{*}{ Advantages } & \multirow{2}{*}{ Limitations } & \multicolumn{4}{|l|}{ Exemplary studies } \\
\hline & & & Authors & Wound Therapy & Materials \& Methods & Outcome Parameters \\
\hline \multirow[t]{2}{*}{ dorsal skinfold chamber } & \multirow{2}{*}{$\begin{array}{l}\text { repetitive intravital } \\
\text { fluorescence microscopy } \\
\text { (high resolution) } \\
\text { repetitive planimetry of } \\
\text { wound surface } \\
\text { elimination of breathing } \\
\text { artifacts } \\
\text { suitable in all mouse strains } \\
\text { implantation of biomaterials, } \\
\text { wound dressings } \\
\text { restricted wound contraction }\end{array}$} & \multirow{2}{*}{$\begin{array}{l}\text { animal distress } \\
\text { limited observation period } \\
\text { (max. } 21 \text { days) } \\
\text { chamber tilting (drop out } \\
20 \% \text { ) } \\
\text { requires microsurgical } \\
\text { preparation }\end{array}$} & Schreiter et al., 2020 & Insulin & $\begin{array}{l}\text { BKS.Cg- Dock7m +/+ } \\
\text { Leprdb/J mice, } \\
\text { Staphylococcus aureus } \\
\text { ATCC 49230, } \\
\text { densitometry, IVM, } \\
\text { fluorescence in situ } \\
\text { hybridization, } \\
\text { stainings: MmP9, Dapi }\end{array}$ & $\begin{array}{l}\text { angiogenesis, biofilm } \\
\text { formation, colony } \\
\text { forming units, } \\
\text { macrophage count, } \\
\text { extracellular matrix } \\
\text { composition, wound } \\
\text { size, inflammation }\end{array}$ \\
\hline & & & McLuckie et al., 2020 & $\begin{array}{l}\text { microvascular-rich } \\
\text { lipoconstructs }\end{array}$ & $\begin{array}{l}\text { IVM } \\
\text { stainings: H\&E, } \\
\text { alpha-SMA, Masson's } \\
\text { trichrome }\end{array}$ & $\begin{array}{l}\text { microvessel length, } \\
\text { functional microvessel } \\
\text { density, vascular } \\
\text { diameter, capillary } \\
\text { diameter, collagen } \\
\text { density and } \\
\text { development, } \\
\text { inflammation }\end{array}$ \\
\hline \multirow{2}{*}{$\begin{array}{l}\text { hairless mouse } \\
\text { ear model }\end{array}$} & \multirow{2}{*}{$\begin{array}{l}\text { repetitive intravital } \\
\text { fluorescence microscopy } \\
\text { repetitive planimetry of } \\
\text { wound surface } \\
\text { no microsurgery required } \\
\text { restricted wound contraction } \\
\text { (requires intact cartilage), } \\
\text { long-term observation }\end{array}$} & \multirow{2}{*}{$\begin{array}{l}\text { restricted to hairless mice } \\
\text { (for max. IVM quality), } \\
\text { restricted to mice }<12 \\
\text { weeks } \\
\text { low intravital microscopy } \\
\text { quality in long-term } \\
\text { experiments } \\
\text { enables intermittent } \\
\text { wound treatment only } \\
\text { (e.g., plasma treatment) }\end{array}$} & Yellowley et al., 2019 & $\begin{array}{l}\text { circulating } \\
\text { progenitor cells }\end{array}$ & $\begin{array}{l}\text { PCR/FACS of circulating } \\
\text { cells }\end{array}$ & $\begin{array}{l}\text { wound size, Angptl4, } \\
\text { Cxcl12 and Cxcr4 RNA } \\
\text { expression, local Cxcr4 } \\
\text { and Cxvl12 expression }\end{array}$ \\
\hline & & & $\begin{array}{l}\text { Zhuravleva et al., } \\
2020\end{array}$ & cingulin knock-out & $\begin{array}{l}\text { IVM, cingulin knock-out } \\
\text { mice }\end{array}$ & $\begin{array}{l}\text { leakage, red blood cell } \\
\text { velocity, vessel diameter, } \\
\text { leucocytes }\end{array}$ \\
\hline
\end{tabular}


Table 2. Cont.

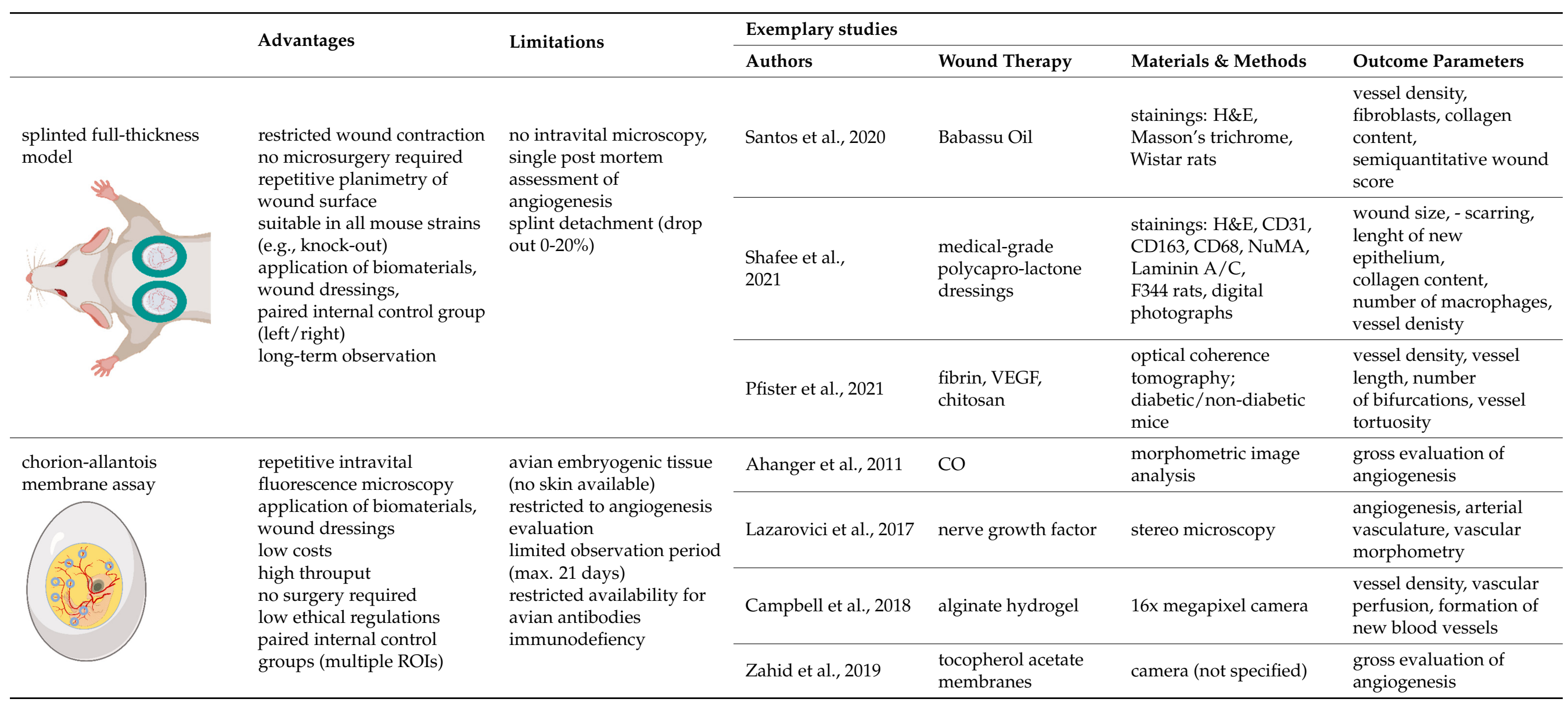



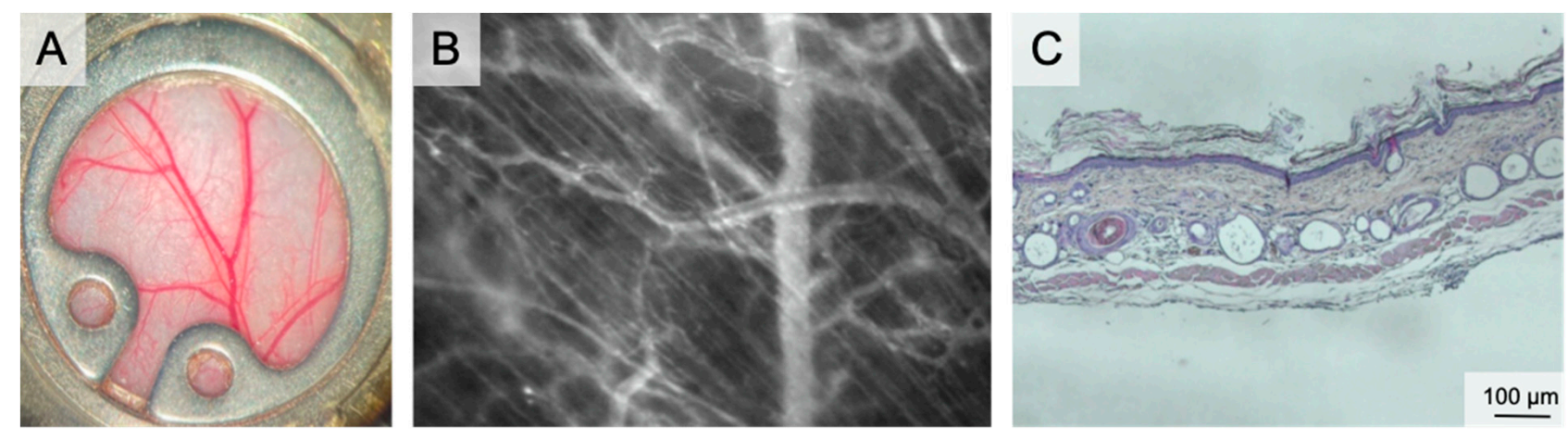

Figure 1. The dorsal skinfold chamber. (A) macroscopic image of the dorsal skinfold chamber following preparation of the subcutaneous vasculature. The chamber is filled with saline and closed by a coverslip. (B) Intravital microscopy showing the microvascular network including capillaries, venules and arterioles in $100 \times$ magnification following iv FITC-dextran injection. (C) Overview of the dorsal skinfold chamber anatomy in HE staining.

The chamber comprises two titanium frames fixing the extended dorsal skin in the back's midline. The skin is sutured to one side of the frame. The microsurgical preparation comprises the removal of the skin, the subcutaneous tissue and the striated panniculus carnosus muscle on one side of the dorsal skinfold. This microsurgery reveals the vessels of the opposite panniculus carnosus muscle. The exposed area can be prepared either in total or only partially. Partial preparation is performed for analysis of wound healing. Finally, the second frame of the chamber is connected by screws and the observation window is filled with saline followed by sealing with a coverslip [35]. The observation window has a diameter of $12 \mathrm{~mm}$. Wound healing can be studied both under wet and dry conditions by using a glass coverslip or by leaving the wound uncovered. Since the chamber allows placement of biomaterials or any kind of solid, gel or liquid wound coverage, this model can assess the effect of external wound therapies.

The vascular pattern and its changes during the observation period were described recently. The wound edges show typical circular vascular architecture with outer radial and inner circular arranged vessels in the re-surfacing skin. As a sign of physiologic maturation, the density of the circular vessels decreases until day 12 [5].

In skin wound healing, planimetric evaluation of the wound diameter/area is the primary outcome. Microvascular parameters are studied by IVM, which enables visualization of the blood flow in arterioles, venules, and capillaries upon iv injection of fluorescein isothiocyanate-labeled dextran. In addition, local inflammation can be assessed upon iv injection of rhodamine-6G, which labels leukocytes and enables the study of leukocyte count, rolling, and transmigration into the wound bed. They allow for real-time visualization of morphological and dynamic changes of the microvascular network of the wound ground and edge over the time. As another non-invasive imaging technique, hyperspectral imaging can be performed to visualize and measure vascular hemoglobin saturation without injection of contrast agents. Repetitive intravital measurements can be performed for up to 21 days [36]. Fixation of the chamber during IVM reduces motion artefacts to facilitate a smooth microscopy.

The dorsal skinfold chamber is a sophisticated model and allows for angiogenesis and wound healing studies in different pathological settings without restriction to certain mouse strains (such as hairless mice). Any transgenic (knockout or chimeric) mice can be used for dorsal skinfold chamber experiments in a standardized setup. In this context, the model was used for analysis of wound healing and angiogenesis of diabetic wounds in mutant diabetic mice (db; BKS.Cg-m+/+Lepr (db)/J) [37]. 
Regarding the importance of $3 R$ (replacement, reduction, refinement), repetitive examination of the same animal reduces the experimental groups. The chamber continuously exposes the wound and the microenvironment to IVM, without further surgery (Refinement).

Different software tools can perform quantification of microcirculatory or inflammatory parameters. One common tool is the CapImage ${ }^{\circledR}$ Software (Dr. Zeintl Software, Heidelberg, Germany) [38]. This allows quantification of vascular diameters, red blood cell velocity, functional capillary density, area quantification or quantification of microvascular leakage through intra- and extravascular grey scale values. This software has been used for several years, but still lacks automated analysis. Sophisticated programs use artificial intelligence for automated assessment of vascular parameters. In this context, open-source programs like ImageJ [39] or Matlab [40] are available for assessment of capillary density, vascular diameter, and other microvascular parameters in a fast, time-efficient and reliable way. While automated image analysis is well established, video analysis of dynamic intravital interactions must be developed.

Although the dorsal skinfold chamber model in mice bears several important advantages, there are considerable limitations. Since the titanium chamber with a weight of $3.8 \mathrm{~g}$ is fixed on the back of the mice, the chamber will tilt laterally over time (day 10+). This issue is pronounced in obese mice, which are frequently used to study the effect of diabetes or dyslipidemia on wound healing. Since tilting is associated with distress, pain and skin ulceration, up to $20 \%$ of the experiments need to be stopped between day 12 and 21 . Another problem that comes with tilting of the chamber is compromised microcirculation by kinking of dorsal skin arteries and veins. Suppressed circulation may be an additional variable in wound healing and microcirculation.

The tight fixation of the chamber, which prevents wound contraction, may compress the perfusion of the dorsal skin tissue, and therefore lead to the same complications as chamber tilting.

Quality and reliability of IVM are directly associated with the quality of the microsurgical preparation of the dorsal skin and muscle. Even a perfectly prepared chamber with optimal conditions for IVM will worsen over time because of healing processes which are associated with fibrin formation and exudation. These impair the penetration depth of IVM, reduce the contrast and lead to blurred images, which impede off-line analysis of capillary perfusion, leukocyte rolling and transmigration, which need high-resolution recording. Reopening and cleaning of the chamber should be omitted because it affects the wound bed and therefore the microcirculatory analysis. Other risk factors for blurred recordings, such as bleeding, hematoma formation and infections can be avoided by meticulous preparation.

In summary, the dorsal skinfold chamber model proved a valuable tool to study angiogenesis and microcirculation during wound healing.

\subsection{The Splinted Full Thickness Model}

Compared to wound healing in humans, which is primarily based on formation of granulation tissue and re-epithelialization, the major mechanism of wound healing in rodents is wound closure by contraction [41]. To overcome this drawback, Galiano et al. developed the splinted full thickness model in mice [42].

Anesthetized mice are first shaved and depilated. Two symmetrical full-thickness wounds extending through the panniculus carnosus are created on the dorsum of mice using a skin biopsy punch and microsurgical scissors. To avoid wound contraction, a donutshaped, $5 \mathrm{~mm}$-thick silicon splint is fixed on the wound with immediate-bonding adhesive and interrupted nylon sutures. Afterwards, the wound is covered with an occlusive dressing [42,43].

The splinted full thickness model enables direct application of topical agents on the wound bed or assessment of wound healing upon systemically pharmacological treatment. In parallel to other murine wound healing models, it also allows the study of wound healing in different pathological conditions, e.g., renal dysfunction [44], using respective transgenic or knockout mice. The splinted wound model was recently applied in rats to 
study hypertrophic scarring [45] and to study new splint constructions [46]. Since its first description in 2004 by Galiano et al., several further developments of the splint model were described, including nitinol splints [46], and plastic ring-shaped splints to assessment the total length of wound epithelialization, including dermal remodeling and regenerative epithelialization [47] or glue fixed biological membranes and adhesive dressing application on the wound to prevent wound skin contraction, without further surgical affection of the skin by suture fixation [48].

The splinted full thickness model was used study the effects of recombinant myxoma virus-derived immune modulator M-T7 [49], of Babassu oil [50], of three-dimensional printed scaffolds and electrospun mats [51], of adult gingival multipotent mensenchymal stem cells [52], of induced pluripotent stem cells clay [53], of poly(lactic-co-glycolic acid) and vascular endothelial growth factor [54], and of renal dysfunction [44] on cutaneous wound healing.

Analysis of wound healing in this model comprises quantification of wound size by digital photography or stereomicroscopy, histological and immunohistochemical analysis of the wound bed and bioluminescence imaging (e.g., luciferase transfected cells).

This model is surgically simple to perform and to reproduce. The success rate for maintenance of the splint is between $80 \%$ [55] to $100 \%$ [42]. Since two symmetrical wounds are created on the back of each mouse, one can serve as a paired, internal control. Exclusion criteria of wounds are wound infections, fracture, and partial or total detachment of splints from the dorsum.

Compared to the dorsal skinfold chamber model, one benefit of the splinted full thickness model is its lower burden for the animals: low drop-out, short operation time and low weight of the splints. Like the chamber model, the skin is fixed to the splints which avoid contraction and therefore enable translation of the results to human wound healing by migration. At the same time, the splints provide a chamber frame for application and fixation of topical therapeutic agents.

However, the microcirculation and vascularization of the wound bed in the splint full thickness model are primarily studied by post-mortem immunohistochemical staining of, e.g., CD31 or other vascular markers. Since this model is not suitable for IVM, this can be attributed as a disadvantage compared to the ear, the chorion allantois and the skinfold chamber models. Longitudinal analysis of wound healing is only performed by stereomicroscopy or photometric analysis of the wound size, while longitudinal analysis of vascularization or angiogenesis at different time points requires euthanasia of animals at respective intervals, which in turn increases the number of animals and does not comply to the $3 R$.

\subsection{The Hairless Mouse Auricle Model}

Hairless mice (e.g., SKH1-hr ${ }^{\text {hr }}$ ) enable direct functional imaging of auricle vessels and wounds [56-59]. The entire microvascular network, comprising venules, arterioles, and capillaries up to $100 \mu \mathrm{m}$ in diameter, can be visualized and examined in real time. This makes the auricle model suitable for studying wound healing [59-63] axial pattern flaps [57,58,64-66] macromolecular leakage [58], and microvascular thrombus formation [67-69] (Figure 2).

The average thickness of the auricle is $300 \mu \mathrm{m}$. It comprises two dermis layers, separated by cartilage. On the convex dorsal side of the cartilage, three vascular bundles enter the auricle. The venules have diameters of between $200 \mu \mathrm{m}$ (basal) and $10 \mu \mathrm{m}$ (apical). Tightly meshed capillaries surround the empty hair follicles [57]. 

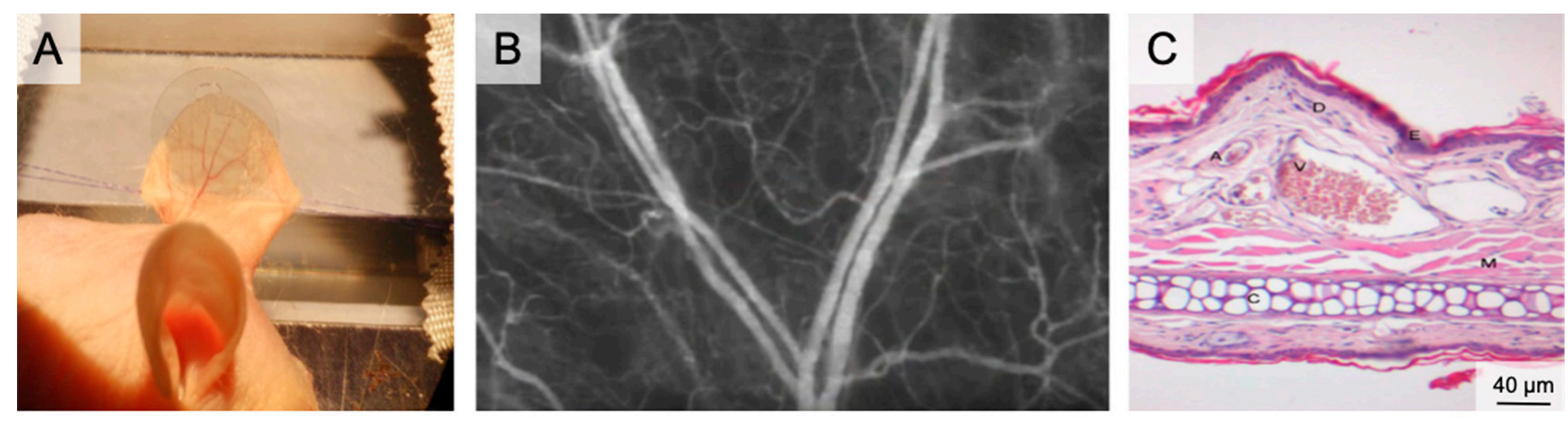

Figure 2. The auricle of the hairless SKH1 $-h^{h r}$ mouse. (A) Positioning of the mouse auricle for intravital microscopy. The image shows the auricle fixed using two 6/0 sutures and after placement of a glass cover slip, which enables water immersion during fluorescence microscopy. (B) Intravital microscopy of the main branching of the neurovascular bundle in 50× magnification following iv FITC-dextran injection. (C) HE histology of the auricle illustrating the rich vasculature (A-arteriole; V-venule; D-dermis; E-epidermis; M-muscle; C-Cartilage).

Examination conditions are ideal for young animals at 4-10 weeks of age and with little keratinization of the epidermis. In older animals, the quality of visualization of the vessels becomes poor because of the greater distance between the skin surface and the target vessels.

Full thickness skin wounds are prepared using micro-scissors to excise skin down to the cartilage layer. Intact cartilage with perichondrium is essential to avoid wound contraction (cartilage) and cartilage necrosis (perichondrium) [61,62]. After wound preparation, repetitive IVM can be performed. IVM requires plane positioning of the auricle and reduction of movement artifacts, which can be achieved by temporary fixation sutures close to the base of the auricle. After fixation, a coverslip is applied and intravital planimetry and microcirculation analysis is performed, as described for the dorsal skinfold chamber model [7].

The primary advantage of the auricle model is the access to the vessels without risk of tissue damage by surgical dissection. Neither inflammation, vasoconstriction nor activation of hemostasis in the hairless mouse ear lobe affect the assessed parameters. Although no surgical dissection is required, image resolution and clarity are comparable to other angiogenesis models.

In terms of animal welfare, the experimental procedure is minimally invasive for the animals, and the mice do not need to recover from major surgery or carry an additional weight, e.g., a titanium chamber, during the experiment.

An important limitation of the auricle model is the restriction to $4-10$ weeks old mice. This is necessary for optimal IVM quality but hinders long-term experiments and the use of transgenic mice. Another drawback is the susceptibility of the auricle to fluorescent dye extravasation and vessel compression. Therefore, the auricle must not be touched after fluorescent dye injection and coverslips must be applied with caution to avoid venous stasis. Even though little surgical preparation is required, surgery must be performed meticulously to preserve the vascularized perichondrium. This demand can be a major reason for non-reproducible results (cartilage necrosis, wound contraction).

However, if the protocol is performed correctly, IVM in the auricle of hairless SKH1 $\mathrm{hr} / \mathrm{hr}$ mouse is a reliable, simple, and efficient tool for the study of wound healing and angiogenesis.

\subsection{The Chorion-Allantois-Membrane (CAM) Assay}

The increasing importance of distress reduction in animal experiments and the persisting limitations of in vitro systems in angiogenesis research demand complementary models. 
The chorion allantois membrane (CAM) of the chicken embryo has therefore been established as a standard angiogenesis model over recent decades [70-81] (Figure 3). The CAM is an extraembryonic structure with a dense capillary network mediating gas and nutrient exchange until hatching on day 21 . The capillary bed connects arterioles $(10-85 \mu \mathrm{m})$ and venules $(10-115 \mu \mathrm{m})$. During embryonic development, the CAM grows from $6 \mathrm{~cm}^{2}$ at day 6 to $65 \mathrm{~cm}^{2}$ at day 14 [79]. Capillary angiogenesis is completed until day 11. Therefore, two phases have to be considered: day 1 to 11 enables experiments on rapidly developing vessels and day 12 to 20 enables research on mature vessels [82-84]. The extracellular matrix between the vessels comprises fibronectin, laminin, collagen type IV and glycosaminoglycans. Single-layer epithelium covers the CAM [77,85].
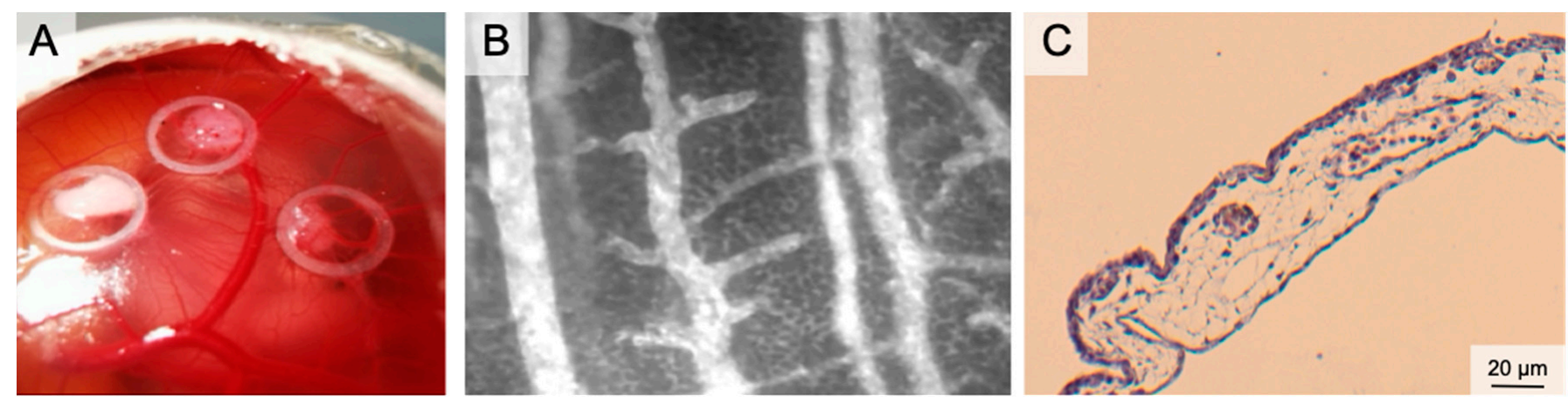

Figure 3. The Chorion Allantois Membrane Assay. (A) Representative macroscopic image of the CAM vessels after implantation of squamous cell carcinoma cells. The tumors grow within silicone rings. (B) Intravital microscopy following iv FITC-dextran injection. The image depicts venules and arterioles surrounded by the dense capillary network. (C) HE staining of the CAM membrane showing well-vascularized connective tissue between the low epithelial layers.

Plenty of in ovo- and ex ovo-preparations have been described to access the CAM. In ovo preparations (window in the eggshell) are easy to perform and have high embryo survival rates. To increase the access to the CAM vasculature, the CAM must be dropped (by draining albumen or manipulation of the air sac). This procedure enables opening of the egg in a horizontal position and exposure of extensive areas of the cam. This is necessary for lens positioning during IVM. Accessibility can further be increased by an ex ovo-setup. In these preparations, the eggshell is removed (usually on day 3); the chicken embryo and the CAM are further cultivated in a petri dish or a sterilized cup [76,86-88]. Ex ovo-preparations reveal the entire CAM for experiments. However, lower survival rates must be considered (in ovo 85-95\%, ex ovo-petri dish 15-25\%, ex ovo-cylindrical vessels $45-95 \%$ ) [89]. Immunodeficiency of the chicken embryo and the engraftment of (human) tumor cells made the CAM a standard model in oncology research for years: studies targeted chemotherapy, irradiation, but also angiogenesis $[70,90]$. Because of the value in tumor angiogenesis research, the CAM emerged as an important model for graft vascularization in tissue engineering [91-94]. Likewise, the CAM has been established in wound healing. Here, the CAM served [78] as a complement to in vitro- and animal in vivo-studies with a focus on angiogenesis. Test substances (CO/NO-releasing molecules, growth factors, nanoparticles or herbal formulations) were administered topically or systemically [95-98]. In tumor angiogenesis, graft placement and CAM wound healing, an increased vessel density and radially converging vessels occur within $72-96 \mathrm{~h}$. For systemic therapy application of large CAM vessels, the albumen and the yolk sac can be punctured [99-103]. Local treatments can be applied to the CAM membrane using silicone rings or loaded matrices $[96,97,104-107]$. The application of sterilized coverslips can also be useful in preventing spatial shifting of implants because of embryo movement.

The main outcome parameters in CAM angiogenesis assays in wound healing are blood vessel density, vessel length and number of branches [95-97]. Most studies performed static analysis of camera pictures at multiple time points during the experiment. CAM 
tumors have been assessed by MRI, CT, PET-CT and ultrasound. However, visualization of angiogenesis requires more distinct methods, such as IVM following intravascular injection of fluorescent dyes (FITC-dextran, Rhodamin-6G). Intravascular injections may cause severe bleeding and fluorescent dye leakage. We recommend using small needles $(30 \mathrm{G}+)$. Fluorescent dye injection into the albumen is a less invasive alternative and enables high-quality recording by vessel transillumination.

Compared to most animal studies, the CAM model is easy to perform, does not require surgical skills and enables a high throughput with low costs $(€ 1.50 / \mathrm{egg})$. The CAM assay also enables repetitive intravital analysis and multiple tests on a single CAM. Another advantage is that most countries do not classify the CAM model as an animal experiment, if the experiment is ended before hatching. Many legislative barriers for animal experiments are not applied and experiments can be performed faster with less administrative expenditure.

However, the chicken embryo reacts to external influences and suffers from blood loss or pain if the embryo is the target of invasive procedures (from day 15) [85]. The CAM itself has no innervation and can be manipulated without harming the embryo. To reduce animal distress, anesthesia should be performed during procedures which target the embryo). IVM during the second and third week of embryo development also requires anesthesia to reduce spontaneous animal movement. Five drops of Ketamin/Xylazin 4:1 administered topically onto the cam were effective in temporary immobilization.

Angiogenesis research must also consider the CAM as a specialized vascular bed; vessels for gas exchange differ from systemic vessels in regulation (lack of innervation and endocrine receptors) and structure (lack of basement membrane). These features are typical for tumor vessels but may be a limitation in wound healing assays [98].

Another limitation for CAM wound healing and angiogenesis assays is the lack of a functional immune system until day 14 to 18 [85]. The unspecific immune reaction in late phase cam experiments may confuse real angiogenesis with rearrangement of existing vessels [108-110]. Hatching follows the development of a functional immune system and limits the CAM assay to a maximum of 21 days. Some local guidelines consider CAM experiments before hatching but beyond day 14 (UK) or day 18 (Germany, Mecklenburg Vorpommern) as animal experiments [85]. The observation time is comparable to the mouse dorsal skinfold chamber, but angiogenesis, wound healing, and tumor growth is faster in the anabolic CAM model.

\section{In Vitro/Ex Vivo Models}

There are several in vitro/ex vivo models of tissue repair that can help answer specific mechanistic questions related to skin wound repair. Many in vitro/ex vivo models are used to answer fundamental questions related to cell-cell interaction, cell signaling in response to cell stress or injury, or cell behavior as a function of various signaling molecules [2] (Figure 4).

In the discussion of in vitro/ex vivo models for the analysis of processes of wound healing the origin of cells or tissues must be critically questioned, especially with a focus on the 3R strategy for the complete avoidance of animal experiments and thus the differentiation from the designation as ex vivo models. However, although many alternative methods are already in use, they cannot yet replace all animal experiments in basic research. Most alternative methods are based on previous animal experiments. In addition, alternative methods can often simulate partial aspects of the extremely complex processes in the human body, as described above. For this reason, it will not be possible to completely dispense with studies on living animals in the foreseeable future. Especially in topical dermatological or cosmetic drug testing, there has long been a call to reduce the use of animal skin models. 


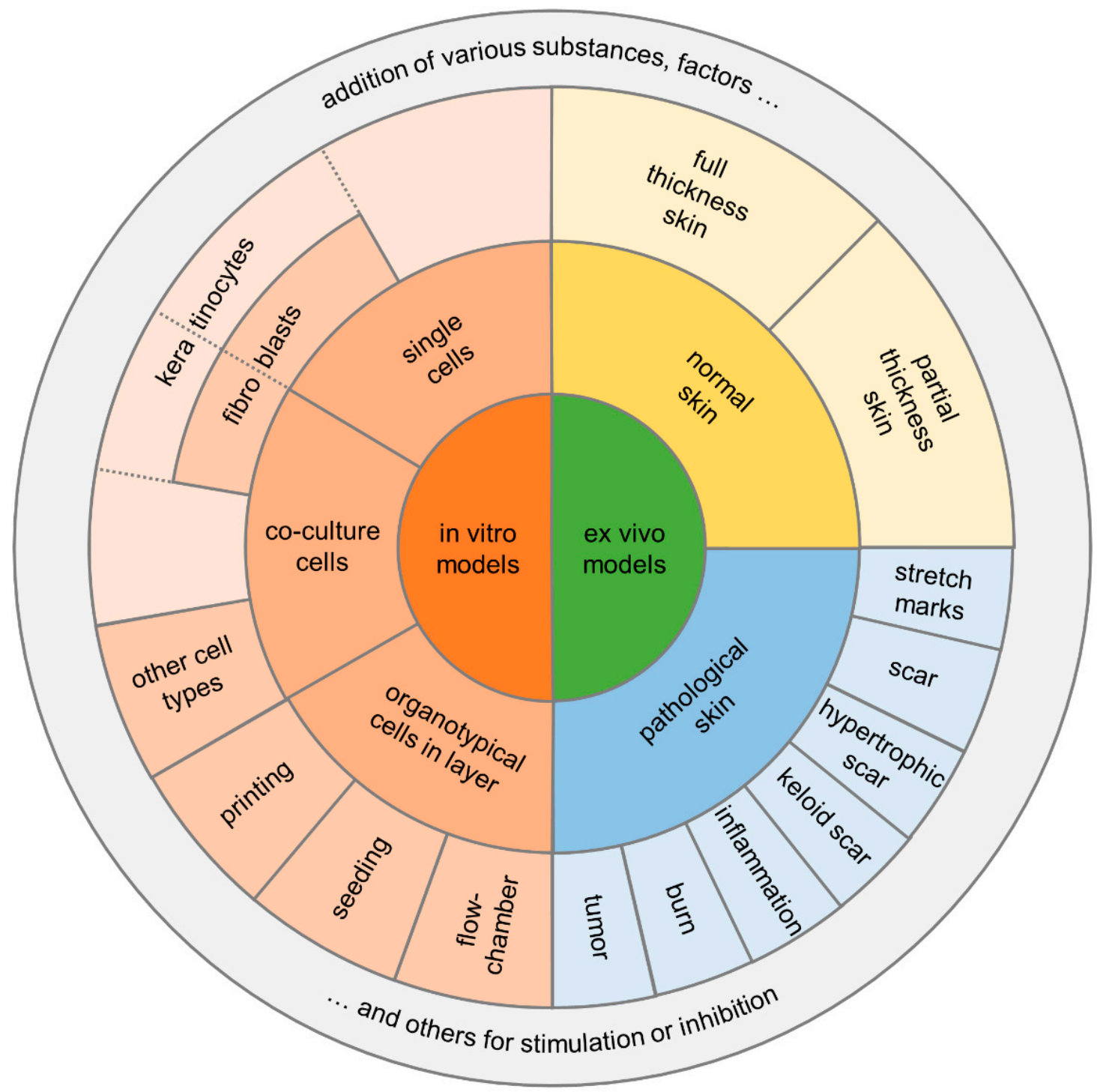

Figure 4. Diagram summarizing the two main categories for in vitro/ex vivo models and their potential assays.

However, simple in vitro models are also justified if the overall process is too complex to understand individual steps or to make very specific statements about cell-cell or cell-factor interactions. Just like the extrapolation of results from animal experiments to humans, in vitro models are also under discussion. For a long time, a major disadvantage of in vitro models has been the restriction to two-dimensional models. Therefore, the three-dimensional anatomical structure of the skin has not been simulated and important interactions have been ignored. Especially, the significance of single cell assays must be queried (because of the lack of endothelial and immune cells). In this context, attempts have therefore been made for some time to construct the in vitro/ex vivo skin models in such a way that they resemble the 3D structure. Of course, the various functions of the skin must also be considered in their entirety. To increase the reliability of the results, different components such as blood vessels [111], immune functions [112], pigmentation [113,114], innervation [115] and appendages [116] are integrated into these 3D models [117,118]. Here, blood vessel supply and new vessel formation are of special research interest. Vascularization of skin constructs within the dermal compartment has been repeatedly investigated by co-culturing with endothelial cells [113]. Since vascularization is of great importance, different pre-seeded scaffolds or 3D printing techniques have also been applied for this purpose to mimic the subcutaneous circulation [118-120]. However, morphological studies 
have shown that although endothelialization occurs, it alters the skin morphology towards an increased maturation process and thus appears more unbalanced [119].

Here, 3D-printing and skin- or wound-on-a chip platforms have been established in recent years. While initially only two-dimensional patterns were possible at the beginning of cell printing, the additional use of various gels or dermal substitute materials soon allowed three-dimensional constructs to be printed and investigated [121-123]. However, vascularization presented itself as a consecutive problem to deliver the engineered tissue, or even organ, to a nutritive perfusion. Direct and indirect vasculature printing techniques were developed to place cells in their specified locations [94]. With these techniques, it is even possible to create complex vascular geometries. However, the cell behavior after printing is considered a challenge, and thus, e.g., porosity, stiffness, cytotoxicity, gelation mechanisms, and interactions with the other polymers or hydrogels must be considered [124].

Recently, skin- or wound-on-a-chip platforms are described as microfluidic technologies [125]. Microfluidic technology offers the possibility to precisely control the fluidic connections and thus the communication between different tissue chambers on the smallest scale $[117,125]$. Micronization of these assays can significantly reduce the cost of experimental setups and general cell or tissue consumption. This experimental model is used to study and validate the physiological relevance of pharmaceuticals or, for example, cell migration in the inflammatory phase [126]. By producing a two-layer skin chip, which contains the epidermal and dermal structures in the upper part, separated by a poly-dimethyl-siloxane (PDMS) membrane, and the fluidic channels and vascular endothelial cells in the lower part, the three-dimensional structure of the skin is now represented [127]. Thus, this micromodel is suitable for a wide range of applications to study physiological but also pathological wound healing, as well as the influence of certain drugs or signal substances on the wound healing process itself.

\section{In Virtuo/In Silico Models}

One of the aims of medical research is to be able to simulate the functions of the organism in a computer model. Therefore, the models to be developed must consider not only the pure structure of the skin, but also biological, bio-chemical, and mechanical factors that influence the healing process or the external influences upon it. This seems of particular interest in the field of wound healing, as there were already several approaches around the turn of the millennium to calculating the processes of epidermal wound healing, remodeling of the dermal extracellular matrix, wound contraction, and angiogenesis with appropriate computer models [128]. Animal experiments would thus no longer be necessary.

However, digitization does not cease in science, and for some time now digital, in virtuo or in silico wound healing models have been described that can reproduce isolated organ and cell functions on the computer [2]. Computer modeling of biochemical processes can be a powerful tool that provides a better understanding of biological systems.

The first step in simulating a biological process is to create a mathematical model (set of equations) that is appropriate for the biological features being studied. The method, known as discretization, allows biological phenomena to be simulated at different levels of complexity. Angiogenesis is precisely regulated by genetic programs and strongly modulated by various chemical factors that enable the activation of cellular signaling pathways. Continuum models [129-131] and cell-based models [132,133] are available mathematical approaches for simulating angiogenesis in wound healing [134]. While cell-based models are used to modulate cell populations and thus allow the behavior of single cells to be studied, continuum models are used to modulate concentrations of chemical mediators. However, for an accurate simulation, which phase of angiogenesis is studied is crucial to create an adequate model and thus reduce the influencing factors on the mathematical model. This is considered a clear disadvantage when investigating the use of these models. 
Recently, hybrid models have been used to combine the cellular level (microscale analysis) with the tissue level (macroscale analysis) [134]. Thus, in angiogenesis analysis, continuum models are often used to describe the behavior of cell populations and chemical concentrations at the tissue scale, using a system of partial differential equations. In studies of, for example, oxygenation in wound healing, the computer-simulated results were in accordance with published experimental literature data [134]. However, there are also disadvantages to be considered here, and so a very close communication and cooperation between life science researchers and mathematicians is required, on the one hand to name the possible biological influences in the context of wound healing, and on the other hand to transfer these influences into correct and adequate computational models.

\section{Conclusions}

Recently, in vitro wound healing models have been substantially improved. In virtuo models have been developed and enable the calculation of different phases of wound healing of the skin. Therefore, safety and efficacy of novel approaches in skin wound healing should first be evaluated in vitro or even in virtuo. However, transferability of the results is often limited because of the complex processes involved in wound healing, and animal models cannot yet be replaced regarding angiogenesis and wound healing research. In addition, in vivo or on vitro models also provide the basis of calculations for all in virtuo models. Multiple animal models have been developed in recent decades with individual strengths and limitations. Both must be addressed to limit animal numbers and increase validity of in vivo experiments. In the proposed selection of in vivo models, the CAM assay is closest to the in vitro models, allowing for high throughput screening of multiple substances with unique access to the vascular bed. On the other hand, the chicken embryo is no mammal, and the model lacks skin; both limit the impact of the model. The most elaborate model for skin wound healing is the dorsal skinfold chamber: multiple microvascular parameters can be assessed in well-standardized wounds. However, animal distress, drop-outs and the limited observation time have to be considered as main disadvantages.

In summary, all the models highlighted in this review bear advantages and disadvantages that must be considered when planning experimental studies on skin wound healing. We hope that this review will help the reader find the most suitable model for the planned approach, and that it might reduce unrewarding experiments because of unknown limitations of respective models.

Author Contributions: Conceptualization, E.G., H.S., D.S.; writing—original draft preparation, E.G., H.S., D.S. writing-review and editing, E.G., H.S., C.G.G.S., D.S.; visualization, E.G., H.S., D.S.; supervision, H.S., C.G.G.S.; project administration, C.G.G.S., D.S. All authors have read and agreed to the published version of the manuscript.

Funding: This research received no external funding.

Institutional Review Board Statement: Not applicable.

Informed Consent Statement: Not applicable.

Conflicts of Interest: The authors declare no conflict of interest.

\section{References}

1. Sorg, H.; Tilkorn, D.J.; Mirastschijski, U.; Hauser, J.; Kraemer, R. Panta Rhei: Neovascularization, Angiogenesis and Nutritive Perfusion in Wound Healing. Eur. Surg. Res. 2018, 59, 232-241. [CrossRef]

2. Ud-Din, S.; Bayat, A. Non-animal models of wound healing in cutaneous repair: In silico, in vitro, ex vivo, and in vivo models of wounds and scars in human skin. Wound Repair Regen. 2017, 25, 164-176. [CrossRef] [PubMed]

3. Masson-Meyers, D.S.; Andrade, T.A.M.; Caetano, G.F.; Guimaraes, F.R.; Leite, M.N.; Leite, S.N.; Frade, M.A.C. Experimental models and methods for cutaneous wound healing assessment. Int. J. Exp. Pathol. 2020, 101, 21-37. [CrossRef]

4. Parnell, L.K.S.; Volk, S.W. The Evolution of Animal Models in Wound Healing Research: 1993-2017. Adv. Wound Care 2019, 8, 692-702. [CrossRef] [PubMed] 
5. Sorg, H.; Krueger, C.; Vollmar, B. Intravital insights in skin wound healing using the mouse dorsal skin fold chamber. J. Anat. 2007, 211, 810-818. [CrossRef] [PubMed]

6. Hergert, B.; Grambow, E.; Butschkau, A.; Vollmar, B. Effects of systemic pretreatment with CpG oligodeoxynucleotides on skin wound healing in mice. Wound Repair Regen. 2013, 21, 723-729. [CrossRef]

7. Strüder, D.; Grambow, E.; Klar, E.; Mlynski, R.; Vollmar, B. Intravital Microscopy and Thrombus Induction in the Earlobe of a Hairless Mouse. J. Vis. Exp. 2017. [CrossRef]

8. Sorg, H.; Krueger, C.; Schulz, T.; Menger, M.D.; Schmitz, F.; Vollmar, B. Effects of erythropoietin in skin wound healing are dose related. FASEB J. 2009, 23, 3049-3058. [CrossRef]

9. Endrich, B.; Laprell-Moschner, C.; Brendel, W.; Messmer, K. Effects of prolonged cold injury on the subcutaneous microcirculation of the hamster. I. Technique, morphology and tissue oxygenation. Res. Exp. Med. 1982, 181, 49-61. [CrossRef] [PubMed]

10. Michael, S.; Sorg, H.; Peck, C.-T.; Koch, L.; Deiwick, A.; Chichkov, B.; Vogt, P.M.; Reimers, K. Tissue engineered skin substitutes created by laser-assisted bioprinting form skin-like structures in the dorsal skin fold chamber in mice. PLoS ONE 2013, 8, e57741. [CrossRef]

11. Michael, S.; Sorg, H.; Peck, C.-T.; Reimers, K.; Vogt, P.M. The mouse dorsal skin fold chamber as a means for the analysis of tissue engineered skin. Burns 2013, 39, 82-88. [CrossRef] [PubMed]

12. Schreiter, J.; Meyer, S.; Schmidt, C.; Schulz, R.M.; Langer, S. Dorsal skinfold chamber models in mice. GMS Interdiscip. Plast. Reconstr. Surg. DGPW 2017, 6, Doc10. [CrossRef] [PubMed]

13. Sorg, H.; Grambow, E.; Eckl, E.; Vollmar, B. Oxytocin effects on experimental skin wound healing. Innov. Surg. Sci. 2017, 2, 219-232. [CrossRef] [PubMed]

14. Ona, G.; Bouso, J.C. Potential safety, benefits, and influence of the placebo effect in microdosing psychedelic drugs: A systematic review. Neurosci. Biobehav. Rev. 2020, 119, 194-203. [CrossRef]

15. Kunos, C.A.; Howells, R.; Chauhan, A.; Myint, Z.W.; Bernard, M.E.; El Khouli, R.; Capala, J. Radiopharmaceutical Validation for Clinical Use. Front. Oncol. 2021, 11, 630827. [CrossRef]

16. Lehr, H.A.; Leunig, M.; Menger, M.D.; Nolte, D.; Messmer, K. Dorsal skinfold chamber technique for intravital microscopy in nude mice. Am. J. Pathol. 1993, 143, 1055-1062.

17. Schreiter, J.S.; Beescho, C.; Kang, J.; Kursawe, L.; Moter, A.; Kikhney, J.; Langer, S.; Osla, F.; Wellner, E.; Kurow, O. New model in diabetic mice to evaluate the effects of insulin therapy on biofilm development in wounds. GMS Interdiscip. Plast. Reconstr. Surg. DGPW 2020, 9, Doc06. [CrossRef]

18. McLuckie, M.; Robotti, F.; Sanchez-Macedo, N.; Enderlin, D.; Frese, L.; Cheng, P.F.; Levesque, M.P.; Egaña, J.T.; Poulikakos, D.; Ferrari, A.; et al. Lipoconstruct surface topography grating size influences vascularization onset in the dorsal skinfold chamber model. Acta Biomater. 2020, 106, 136-144. [CrossRef]

19. Menger, M.D.; Laschke, M.W.; Vollmar, B. Viewing the microcirculation through the window: Some twenty years experience with the hamster dorsal skinfold chamber. Eur. Surg. Res. 2002, 34, 83-91. [CrossRef]

20. Butschkau, A.; Nagel, P.; Grambow, E.; Zechner, D.; Broze, G.J.; Vollmar, B. Contribution of protein Z and protein Z-dependent protease inhibitor in generalized Shwartzman reaction. Crit. Care Med. 2013, 41, e447-e456. [CrossRef]

21. Dahmke, I.N.; Ampofo, E.; Menger, M.D.; Laschke, M.W. The dorsal skinfold chamber: A valuable model for the in vivo evaluation of topical formulations. Exp. Dermatol. 2019, 28, 940-947. [CrossRef]

22. Grambow, E.; Mueller-Graf, F.; Delyagina, E.; Frank, M.; Kuhla, A.; Vollmar, B. Effect of the hydrogen sulfide donor GYY4137 on platelet activation and microvascular thrombus formation in mice. Platelets 2014, 25, 166-174. [CrossRef]

23. Ampofo, E.; Später, T.; Müller, I.; Eichler, H.; Menger, M.D.; Laschke, M.W. The Marine-Derived Kinase Inhibitor Fascaplysin Exerts Anti-Thrombotic Activity. Mar. Drugs 2015, 13, 6774-6791. [CrossRef] [PubMed]

24. Grambow, E.; Leppin, C.; Leppin, K.; Kundt, G.; Klar, E.; Frank, M.; Vollmar, B. The effects of hydrogen sulfide on plateletleukocyte aggregation and microvascular thrombolysis. Platelets 2017, 28, 509-517. [CrossRef] [PubMed]

25. Boulaftali, Y.; Lamrani, L.; Rouzaud, M.-C.; Loyau, S.; Jandrot-Perrus, M.; Bouton, M.-C.; Ho-Tin-Noé, B. The mouse dorsal skinfold chamber as a model for the study of thrombolysis by intravital microscopy. Thromb. Haemost. 2012, 107, 962-971. [CrossRef] [PubMed]

26. Czabanka, M.; Petrilli, L.L.; Elvers-Hornung, S.; Bieback, K.; Albert Imhof, B.; Vajkoczy, P.; Vinci, M. Junctional Adhesion Molecule-C Mediates the Recruitment of Embryonic-Endothelial Progenitor Cells to the Perivascular Niche during Tumor Angiogenesis. Int. J. Mol. Sci. 2020, 21, 1209. [CrossRef] [PubMed]

27. Engelmann, D.; Mayoli-Nüssle, D.; Mayrhofer, C.; Fürst, K.; Alla, V.; Stoll, A.; Spitschak, A.; Abshagen, K.; Vollmar, B.; Ran, S.; et al. E2F1 promotes angiogenesis through the VEGF-C/VEGFR-3 axis in a feedback loop for cooperative induction of PDGF-B. J. Mol. Cell Biol. 2013, 5, 391-403. [CrossRef]

28. Ludwig, N.; Szczepanski, M.J.; Gluszko, A.; Szafarowski, T.; Azambuja, J.H.; Dolg, L.; Gellrich, N.-C.; Kampmann, A.; Whiteside, T.L.; Zimmerer, R.M. CD44(+) tumor cells promote early angiogenesis in head and neck squamous cell carcinoma. Cancer Lett. 2019, 467, 85-95. [CrossRef]

29. Körbel, C.; Gerstner, M.D.; Menger, M.D.; Laschke, M.W. Notch signaling controls sprouting angiogenesis of endometriotic lesions. Angiogenesis 2018, 21, 37-46. [CrossRef] 
30. Rudzitis-Auth, J.; Fuß, S.A.; Becker, V.; Menger, M.D.; Laschke, M.W. Inhibition of erythropoietin-producing hepatoma receptor B4 (EphB4) signalling suppresses the vascularisation and growth of endometriotic lesions. Br. J. Pharmacol. 2020, 177, 3225-3239. [CrossRef]

31. Dau, M.; Volprich, L.; Grambow, E.; Vollmar, B.; Frerich, B.; Al-Nawas, B.; Kämmerer, P.W. Collagen membranes of dermal and pericardial origin-In vivo evolvement of vascularization over time. J. Biomed. Mater. Res. Part A 2020, 108, 2368-2378. [CrossRef] [PubMed]

32. Jehn, P.; Winterboer, J.; Kampmann, A.; Zimmerer, R.; Spalthoff, S.; Dittmann, J.; Gellrich, N.-C.; Tavassol, F. Angiogenic effects of mesenchymal stem cells in combination with different scaffold materials. Microvasc. Res. 2020, 127, 103925. [CrossRef]

33. Schmauss, D.; Weinzierl, A.; Schmauss, V.; Harder, Y. Common Rodent Flap Models in Experimental Surgery. Eur. Surg. Res. 2018, 59, 255-264. [CrossRef] [PubMed]

34. Harder, Y.; Schmauss, D.; Wettstein, R.; Egaña, J.T.; Weiss, F.; Weinzierl, A.; Schuldt, A.; Machens, H.-G.; Menger, M.D.; Rezaeian, F. Ischemic tissue injury in the dorsal skinfold chamber of the mouse: A skin flap model to investigate acute persistent ischemia. J. Vis. Exp. 2014, e51900. [CrossRef] [PubMed]

35. Laschke, M.W.; Menger, M.D. The dorsal skinfold chamber: A versatile tool for preclinical research in tissue engineering and regenerative medicine. Eur. Cell. Mater. 2016, 32, 202-215. [CrossRef]

36. Prunier, C.; Chen, N.; Ritsma, L.; Vrisekoop, N. Procedures and applications of long-term intravital microscopy. Methods 2017, 128, 52-64. [CrossRef]

37. Langer, S.; Beescho, C.; Ring, A.; Dorfmann, O.; Steinau, H.U.; Spindler, N. A new in vivo model using a dorsal skinfold chamber to investigate microcirculation and angiogenesis in diabetic wounds. GMS Interdiscip. Plast. Reconstr. Surg. DGPW 2016, 5, Doc09. [CrossRef]

38. Klyscz, T.; Jünger, M.; Jung, F.; Zeintl, H. Cap Image-ein neuartiges computerunterstütztes Videobildanalysesystem für die dynamische Kapillarmikroskopie. Biomed. Tech. 1997, 42, 168-175. [CrossRef]

39. Schneider, C.A.; Rasband, W.S.; Eliceiri, K.W. NIH Image to ImageJ: 25 years of image analysis. Nat. Methods 2012, 9, 671-675. [CrossRef]

40. Biel, N.M.; Lee, J.A.; Sorg, B.S.; Siemann, D.W. Limitations of the dorsal skinfold window chamber model in evaluating anti-angiogenic therapy during early phase of angiogenesis. Vasc. Cell 2014, 6, 17. [CrossRef]

41. Davidson, J.M. Animal models for wound repair. Arch. Dermatol. Res. 1998, 290, S1-S11. [CrossRef]

42. Galiano, R.D.; Michaels, J.; Dobryansky, M.; Levine, J.P.; Gurtner, G.C. Quantitative and reproducible murine model of excisional wound healing. Wound Repair Regen. 2004, 12, 485-492. [CrossRef]

43. Pfister, M.; Schützenberger, K.; Schäfer, B.J.; Puchner, S.; Stegmann, H.; Hohenadl, C.; Mildner, M.; Garhöfer, G.; Schmetterer, L.; Werkmeister, R.M. Optical Coherence Tomography Angiography Monitors Cutaneous Wound Healing under AngiogenesisPromoting Treatment in Diabetic and Non-Diabetic Mice. Appl. Sci. 2021, 11, 2447. [CrossRef]

44. Xie, P.; Young, M.W.; Bian, H.; Niknam-Bienia, S.; Hong, S.; Mustoe, T.A.; Galiano, R.D. Renal dysfunction aggravated impaired cutaneous wound healing in diabetic mice. Wound Repair Regen. 2019, 27, 49-58. [CrossRef]

45. Son, D.O.; Hinz, B. A Rodent Model of Hypertrophic Scarring: Splinting of Rat Wounds. Methods Mol. Biol. 2021, 2299, 405-417. [CrossRef] [PubMed]

46. Baek, S.O.; Jang, U.; Shin, J.; Kim, J.H.; Kim, J.H.; Lee, J.Y. Shape memory alloy as an internal splint in a rat model of excisional wound healing. Biomed. Mater. 2021, 16, 25002. [CrossRef]

47. Jimi, S.; de Francesco, F.; Ferraro, G.A.; Riccio, M.; Hara, S. A Novel Skin Splint for Accurately Mapping Dermal Remodeling and Epithelialization During Wound Healing. J. Cell. Physiol. 2017, 232, 1225-1232. [CrossRef] [PubMed]

48. Yao, Z.; Huang, Y.; Luo, G.; Wu, J.; He, W. A biological membrane-based novel excisional wound-splinting model in mice (with video). Burns Trauma 2014, 2, 196-200. [CrossRef] [PubMed]

49. Yaron, J.R.; Zhang, L.; Guo, Q.; Awo, E.A.; Burgin, M.; Schutz, L.N.; Zhang, N.; Kilbourne, J.; Daggett-Vondras, J.; Lowe, K.M.; et al. Recombinant Myxoma Virus-Derived Immune Modulator M-T7 Accelerates Cutaneous Wound Healing and Improves Tissue Remodeling. Pharmaceutics 2020, 12, 1003. [CrossRef]

50. Santos, J.A.A.; Da Silva, J.W.; Dos Santos, S.M.; Rodrigues, M.d.F.; Silva, C.J.A.; Da Silva, M.V.; Correia, M.T.S.; Albuquerque, J.F.C.; Melo, C.M.L.; Silva, T.G.; et al. In Vitro and In Vivo Wound Healing and Anti-Inflammatory Activities of Babassu Oil (Attalea speciosa Mart. Ex Spreng., Arecaceae). Evid. Based Complement. Alternat. Med. 2020, 2020, 8858291. [CrossRef]

51. Nun, N.; Cruz, M.; Jain, T.; Tseng, Y.-M.; Menefee, J.; Jatana, S.; Patil, P.S.; Leipzig, N.D.; McDonald, C.; Maytin, E.; et al. Thread Size and Polymer Composition of 3D Printed and Electrospun Wound Dressings Affect Wound Healing Outcomes in an Excisional Wound Rat Model. Biomacromolecules 2020, 21, 4030-4042. [CrossRef]

52. Shafiee, A.; Cavalcanti, A.S.; Saidy, N.T.; Schneidereit, D.; Friedrich, O.; Ravichandran, A.; De-Juan-Pardo, E.M.; Hutmacher, D.W. Convergence of 3D printed biomimetic wound dressings and adult stem cell therapy. Biomaterials 2021, 268, 120558. [CrossRef]

53. Clayton, Z.E.; Tan, R.P.; Miravet, M.M.; Lennartsson, K.; Cooke, J.P.; Bursill, C.A.; Wise, S.G.; Patel, S. Induced pluripotent stem cell-derived endothelial cells promote angiogenesis and accelerate wound closure in a murine excisional wound healing model. Biosci. Rep. 2018, 38, BSR20180563. [CrossRef] [PubMed]

54. Chereddy, K.K.; Lopes, A.; Koussoroplis, S.; Payen, V.; Moia, C.; Zhu, H.; Sonveaux, P.; Carmeliet, P.; Des Rieux, A.; Vandermeulen, G.; et al. Combined effects of PLGA and vascular endothelial growth factor promote the healing of non-diabetic and diabetic wounds. Nanomedicine 2015, 11, 1975-1984. [CrossRef] [PubMed] 
55. Park, S.A.; Teixeira, L.B.C.; Raghunathan, V.K.; Covert, J.; Dubielzig, R.R.; Isseroff, R.R.; Schurr, M.; Abbott, N.L.; McAnulty, J.; Murphy, C.J. Full-thickness splinted skin wound healing models in $\mathrm{db} / \mathrm{db}$ and heterozygous mice: Implications for wound healing impairment. Wound Repair Regen. 2014, 22, 368-380. [CrossRef] [PubMed]

56. Eriksson, E.; Boykin, J.V.; Pittman, R.N. Method for in vivo microscopy of the cutaneous microcirculation of the hairless mouse ear. Microvasc. Res. 1980, 19, 374-379. [CrossRef]

57. Benavides, F.; Oberyszyn, T.M.; VanBuskirk, A.M.; Reeve, V.E.; Kusewitt, D.F. The hairless mouse in skin research. J. Dermatol. Sci. 2009, 53, 10-18. [CrossRef]

58. Barker, J.H.; Hammersen, F.; Bondàr, I.; Uhl, E.; Galla, T.J.; Menger, M.D.; Messmer, K. The hairless mouse ear for in vivo studies of skin microcirculation. Plast. Reconstr. Surg. 1989, 83, 948-959. [CrossRef]

59. Goertz, O.; Ring, A.; Knie, U.; Abels, C.; Daigeler, A.; Steinau, H.-U.; Steinstraesser, L.; Langer, S. Evaluation of a novel polihexanide-preserved wound covering gel on dermal wound healing. Eur. Surg. Res. 2010, 44, 23-29. [CrossRef]

60. Goertz, O.; Baerreiter, S.; Ring, A.; Jettkant, B.; Hirsch, T.; Daigeler, A.; Steinau, H.U.; Langer, S. Determination of microcirculatory changes and angiogenesis in a model of frostbite injury in vivo. J. Surg. Res. 2011, 168, 155-161. [CrossRef]

61. Sorg, H.; Schulz, T.; Krueger, C.; Vollmar, B. Consequences of surgical stress on the kinetics of skin wound healing: Partial hepatectomy delays and functionally alters dermal repair. Wound Repair Regen. 2009, 17, 367-377. [CrossRef] [PubMed]

62. Schmidt, A.; Bekeschus, S.; Wende, K.; Vollmar, B.; Woedtke, T. von. A cold plasma jet accelerates wound healing in a murine model of full-thickness skin wounds. Exp. Dermatol. 2017, 26, 156-162. [CrossRef] [PubMed]

63. Yellowley, C.E.; Toupadakis, C.A.; Vapniarsky, N.; Wong, A. Circulating progenitor cells and the expression of Cxcl12, Cxcr4 and angiopoietin-like 4 during wound healing in the murine ear. PLOS ONE 2019, 14, e0222462. [CrossRef]

64. Grambow, E.; Augustin, V.A.; Strüder, D.; Kundt, G.; Klar, E.; Vollmar, B. The effects of hydrogen sulfide on microvascular circulation in the axial pattern flap ear model in hairless mice. Microvasc. Res. 2018, 120, 74-83. [CrossRef] [PubMed]

65. Goertz, O.; Over, H.; von der Lohe, L.; Lauer, H.; Ring, A.; Daigeler, A.; Lehnhardt, M.; Kolbenschlag, J. Prednisolone but not selenium and rtPA reduces edema and improves angiogenesis after burn in mice. Burns 2016, 42, 375-383. [CrossRef]

66. Zhuravleva, K.; Goertz, O.; Wölkart, G.; Guillemot, L.; Petzelbauer, P.; Lehnhardt, M.; Schmidt, K.; Citi, S.; Schossleitner, K. The tight junction protein cingulin regulates the vascular response to burn injury in a mouse model. Microvasc. Res. 2020, $132,104067$. [CrossRef]

67. Roesken, F.; Ruecker, M.; Vollmar, B.; Boeckel, N.; Morgenstern, E.; Menger, M.D. A New Model for Quantitative In Vivo Microscopic Analysis of Thrombus Formation and Vascular Recanalisation: The Ear of the Hairless (hr/hr) Mouse. Thromb. Haemost. 1997, 78, 1408-1414. [CrossRef]

68. Proske, S.; Vollmar, B.; Menger, M.D. Microvascular consequences of thrombosis in small venules: An in vivo microscopic study using a novel model in the ear of the hairless mouse. Thromb Res 2000, 98, 491-498. [CrossRef]

69. Grambow, E.; Strüder, D.; Klar, E.; Hinz, B.; Vollmar, B. Differential effects of endogenous, phyto and synthetic cannabinoids on thrombogenesis and platelet activity. BioFactors 2016, 42, 581-590. [CrossRef]

70. Auerbach, R.; Lewis, R.; Shinners, B.; Kubai, L.; Akhtar, N. Angiogenesis assays: A critical overview. Clin. Chem. 2003, 49, 32-40. [CrossRef] [PubMed]

71. Auerbach, R.; Kubai, L.; Sidky, Y. Angiogenesis induction by tumors embryonic tissues, and lymphocytes. Cancer Res. 1976, 36,3435 .

72. Bobek, V.; Plachy, J.; Pinterova, D.; Kolostova, K.; Boubelik, M.; Jiang, P.; Yang, M.; Hoffman, R.M. Development of a green fluorescent protein metastatic-cancer chick-embryo drug-screen model. Clin. Exp. Metastasis 2004, 21, 347-352. [CrossRef]

73. Conconi, M.T.; Bellini, S.; Teoli, D.; de Coppi, P.; Ribatti, D.; Nico, B.; Simonato, E.; Gamba, P.G.; Nussdorfer, G.G.; Morpurgo, M.; et al. In vitro and in vivo evaluation of acellular diaphragmatic matrices seeded with muscle precursors cells and coated with VEGF silica gels to repair muscle defect of the diaphragm. J. Biomed. Mater. Res. Part A 2009, 89, 304-316. [CrossRef]

74. Conconi, M.T.; Nico, B.; Mangieri, D.; Tommasini, M.; Di Liddo, R.; Parnigotto, P.P.; Nussdorfer, G.G.; Ribatti, D. Angiogenic response induced by acellular aortic matrix in vivo. Anat. Rec. A Discov. Mol. Cell. Evol. Biol. 2004, 281, 1303-1307. [CrossRef]

75. Conconi, M.T.; Nico, B.; Rebuffat, P.; Crivellato, E.; Parnigotto, P.P.; Nussdorfer, G.G.; Ribatti, D. Angiogenic response induced by acellular femoral matrix in vivo. J. Anat. 2005, 207, 79-83. [CrossRef] [PubMed]

76. Knighton, D.R.; Fiegel, V.D.; Phillips, G.D. The assay of angiogenesis. Prog. Clin. Biol. Res. 1991, 365, 291.

77. Ribatti, D. The chick embryo chorioallantoic membrane (CAM). A multifaceted experimental model. Mech. Dev. 2016, 141, 70-77. [CrossRef] [PubMed]

78. Ribatti, D.; Conconi, M.T.; Nico, B.; Baiguera, S.; Corsi, P.; Parnigotto, P.P.; Nussdorfer, G.G. Angiogenic response induced by acellular brain scaffolds grafted onto the chick embryo chorioallantoic membrane. Brain Res. 2003, 989, 9-15. [CrossRef]

79. DeFouw, D.O.; Rizzo, V.J.; Steinfeld, R.; Feinberg, R.N. Mapping of the microcirculation in the chick chorioallantoic membrane during normal angiogenesis. Microvasc. Res. 1989, 38, 136-147. [CrossRef]

80. Lazarovici, P.; Lahiani, A.; Gincberg, G.; Haham, D.; Marcinkiewicz, C.; Lelkes, P.I. Nerve Growth Factor-Induced Angiogenesis: 2. The Quail Chorioallantoic Membrane Assay. Methods Mol. Biol. 2018, 1727, 251-259. [CrossRef]

81. Campbell, K.T.; Stilhano, R.S.; Silva, E.A. Enzymatically degradable alginate hydrogel systems to deliver endothelial progenitor cells for potential revasculature applications. Biomaterials 2018, 179, 109-121. [CrossRef]

82. Schlatter, P.; König, M.F.; Karlsson, L.M.; Burri, P.H. Quantitative study of intussusceptive capillary growth in the chorioallantoic membrane (CAM) of the chicken embryo. Microvasc. Res. 1997, 54, 65-73. [CrossRef] [PubMed] 
83. Oh, S.J.; Jeltsch, M.M.; Birkenhäger, R.; McCarthy, J.E.; Weich, H.A.; Christ, B.; Alitalo, K.; Wilting, J. VEGF and VEGF-C: Specific induction of angiogenesis and lymphangiogenesis in the differentiated avian chorioallantoic membrane. Dev. Biol. 1997, 188, 96-109. [CrossRef]

84. Ausprunk, D.H.; Knighton, D.R.; Folkman, J. Vascularization of normal and neoplastic tissues grafted to the chick chorioallantois. Role of host and preexisting graft blood vessels. Am. J. Pathol. 1975, 79, 597.

85. Ribatti, D. The chick embryo chorioallantoic membrane (CAM) assay. Reprod. Toxicol. 2017, 70, 97-101. [CrossRef]

86. Auerbach, R.; Akhtar, N.; Lewis, R.L.; Shinners, B.L. Angiogenesis assays: Problems and pitfalls. Cancer Metastasis Rev. 2000, 19, 167-172. [CrossRef]

87. Auerbach, R.; Kubai, L.; Knighton, D.; Folkman, J. A simple procedure for the long-term cultivation of chicken embryos. Dev. Biol. 1974, 41, 391-394. [CrossRef]

88. Kunz, P.; Schenker, A.; Sähr, H.; Lehner, B.; Fellenberg, J. Optimization of the chicken chorioallantoic membrane assay as reliable in vivo model for the analysis of osteosarcoma. PLoS ONE 2019, 14, e0215312. [CrossRef]

89. Naik, M.; Brahma, P.; Dixit, M. A Cost-Effective and Efficient Chick Ex-Ovo CAM Assay Protocol to Assess Angiogenesis. Methods Protoc. 2018, 1, 19. [CrossRef] [PubMed]

90. Dünker, N.; Jendrossek, V. Implementation of the Chick Chorioallantoic Membrane (CAM) Model in Radiation Biology and Experimental Radiation Oncology Research. Cancers 2019, 11, 1499. [CrossRef]

91. Blatt, S.; Burkhardt, V.; Kämmerer, P.W.; Pabst, A.M.; Sagheb, K.; Heller, M.; Al-Nawas, B.; Schiegnitz, E. Biofunctionalization of porcine-derived collagen matrices with platelet rich fibrin: Influence on angiogenesis in vitro and in vivo. Clin. Oral Investig. 2020, 24, 3425-3436. [CrossRef] [PubMed]

92. Merckx, G.; Tay, H.; Lo Monaco, M.; van Zandvoort, M.; de Spiegelaere, W.; Lambrichts, I.; Bronckaers, A. Chorioallantoic Membrane Assay as Model for Angiogenesis in Tissue Engineering: Focus on Stem Cells. Tissue Eng. Part B Rev. 2020, 26, 519-539. [CrossRef]

93. Valdes, T.I.; Kreutzer, D.; Moussy, F. The chick chorioallantoic membrane as a novel in vivo model for the testing of biomaterials. J. Biomed. Mater. Res. 2002, 62, 273-282. [CrossRef] [PubMed]

94. Nowak-Sliwinska, P.; Segura, T.; Iruela-Arispe, M.L. The chicken chorioallantoic membrane model in biology, medicine and bioengineering. Angiogenesis 2014, 17, 779-804. [CrossRef] [PubMed]

95. Ahanger, A.A.; Prawez, S.; Kumar, D.; Prasad, R.; Amarpal; Tandan, S.K.; Kumar, D. Wound healing activity of carbon monoxide liberated from CO-releasing molecule (CO-RM). Naunyn Schmiedebergs. Arch. Pharmacol. 2011, 384, 93-102. [CrossRef]

96. Talekar, Y.P.; Apte, K.G.; Paygude, S.V.; Tondare, P.R.; Parab, P.B. Studies on wound healing potential of polyherbal formulation using in vitro and in vivo assays. J. Ayurveda Integr. Med. 2017, 8, 73-81. [CrossRef]

97. Zahid, S.; Khalid, H.; Ikram, F.; Iqbal, H.; Samie, M.; Shahzadi, L.; Shah, A.T.; Yar, M.; Chaudhry, A.A.; Awan, S.J.; et al. Bi-layered $\alpha$-tocopherol acetate loaded membranes for potential wound healing and skin regeneration. Mater. Sci. Eng. C Mater. Biol. Appl. 2019, 101, 438-447. [CrossRef]

98. Burggren, W.; Rojas Antich, M. Angiogenesis in the Avian Embryo Chorioallantoic Membrane: A Perspective on Research Trends and a Case Study on Toxicant Vascular Effects. J. Cardiovasc. Dev. Dis. 2020, 7, 56. [CrossRef]

99. Samak, D.H.; El-Sayed, Y.S.; Shaheen, H.M.; El-Far, A.H.; Onoda, A.; Abdel-Daim, M.M.; Umezawa, M. In-ovo exposed carbon black nanoparticles altered mRNA gene transcripts of antioxidants, proinflammatory and apoptotic pathways in the brain of chicken embryos. Chem.-Biol. Interact. 2018, 295, 133-139. [CrossRef] [PubMed]

100. Adlia, A.; Tomagola, I.; Damayanti, S.; Mulya, A.; Rachmawati, H. Antifibrotic Activity and In Ovo Toxicity Study of LiverTargeted Curcumin-Gold Nanoparticle. Sci. Pharm. 2018, 86, 41. [CrossRef]

101. Schlenk, F.; Werner, S.; Rabel, M.; Jacobs, F.; Bergemann, C.; Clement, J.H.; Fischer, D. Comprehensive analysis of the in vitro and ex ovo hemocompatibility of surface engineered iron oxide nanoparticles for biomedical applications. Arch. Toxicol. 2017, 91, 3271-3286. [CrossRef] [PubMed]

102. Giovannini, G.; Warncke, P.; Fischer, D.; Stranik, O.; Hall, A.J.; Gubala, V. Improving colloidal stability of silica nanoparticles when stored in responsive gel: Application and toxicity study. Nanotoxicology 2018, 12, 407-422. [CrossRef] [PubMed]

103. Kuzyniak, W.; Adegoke, O.; Sekhosana, K.; D’Souza, S.; Tshangana, S.C.; Hoffmann, B.; Ermilov, E.A.; Nyokong, T.; Höpfner, M. Synthesis and characterization of quantum dots designed for biomedical use. Int. J. Pharm. 2014, 466, 382-389. [CrossRef] [PubMed]

104. Álvarez-Álvarez, L.; Barral, L.; Bouza, R.; Farrag, Y.; Otero-Espinar, F.; Feijóo-Bandín, S.; Lago, F. Hydrocortisone loaded poly-(3hydroxybutyrate-co-3-hydroxyvalerate) nanoparticles for topical ophthalmic administration: Preparation, characterization and evaluation of ophthalmic toxicity. Int. J. Pharm. 2019, 568, 118519. [CrossRef] [PubMed]

105. Bakan, B.; Gülcemal, S.; Akgöl, S.; Hoet, P.H.M.; Karabay Yavaşoğlu, N.Ü. Synthesis, characterization and toxicity assessment of a new polymeric nanoparticle, l-glutamic acid-g-p(HEMA). Chem.-Biol. Interact. 2020, 315, 108870. [CrossRef]

106. Katzer, T.; Chaves, P.; Bernardi, A.; Pohlmann, A.; Guterres, S.S.; Ruver Beck, R.C. Prednisolone-loaded nanocapsules as ocular drug delivery system: Development, in vitro drug release and eye toxicity. J. Microencapsul. 2014, 31, 519-528. [CrossRef]

107. Katzer, T.; Chaves, P.; Bernardi, A.; Pohlmann, A.R.; Guterres, S.S.; Beck, R.C.R. Castor oil and mineral oil nanoemulsion: Development and compatibility with a soft contact lens. Pharm. Dev. Technol. 2014, 19, 232-237. [CrossRef]

108. Leene, W.; Duyzings, M.J.; van Steeg, C. Lymphoid stem cell identification in the developing thymus and bursa of Fabricius of the chick. Z. Zellforsch. Mikrosk. Anat. 1973, 136, 521-533. [CrossRef] 
109. Marga Janse, E.; Jeurissen, S.H. Ontogeny and Function of Two Non-Lymphoid Cell Populations in the Chicken Embryo. Immunobiology 1991, 182, 472-481. [CrossRef]

110. Solomon, J.B. Lymphocytopoiesis and ontogeny of defined immunity in birds. In Fetal and Neonatal Immunology; Plenum Press: New York, NY, USA, 1971.

111. Liu, X.; Michael, S.; Bharti, K.; Ferrer, M.; Song, M.J. A biofabricated vascularized skin model of atopic dermatitis for preclinical studies. Biofabrication 2020, 12, 35002. [CrossRef]

112. Bechetoille, N.; Dezutter-Dambuyant, C.; Damour, O.; André, V.; Orly, I.; Perrier, E. Effects of solar ultraviolet radiation on engineered human skin equivalent containing both Langerhans cells and dermal dendritic cells. Tissue Eng. 2007, 13, 2667-2679. [CrossRef] [PubMed]

113. Regazzetti, C.; de Donatis, G.M.; Ghorbel, H.H.; Cardot-Leccia, N.; Ambrosetti, D.; Bahadoran, P.; Chignon-Sicard, B.; Lacour, J.-P.; Ballotti, R.; Mahns, A.; et al. Endothelial Cells Promote Pigmentation through Endothelin Receptor B Activation. J. Investig. Dermatol. 2015, 135, 3096-3104. [CrossRef]

114. Gledhill, K.; Guo, Z.; Umegaki-Arao, N.; Higgins, C.A.; Itoh, M.; Christiano, A.M. Melanin Transfer in Human 3D Skin Equivalents Generated Exclusively from Induced Pluripotent Stem Cells. PLoS ONE 2015, 10, e0136713. [CrossRef] [PubMed]

115. Muller, Q.; Beaudet, M.-J.; de Serres-Bérard, T.; Bellenfant, S.; Flacher, V.; Berthod, F. Development of an innervated tissueengineered skin with human sensory neurons and Schwann cells differentiated from iPS cells. Acta Biomater. 2018, 82, 93-101. [CrossRef]

116. Stahl, J.; Niedorf, F.; Wohlert, M.; Kietzmann, M. The in vitro use of the hair follicle closure technique to study the follicular and percutaneous permeation of topically applied drugs. Altern. Lab. Anim. 2012, 40, 51-57. [CrossRef] [PubMed]

117. Abaci, H.E.; Guo, Z.; Doucet, Y.; Jacków, J.; Christiano, A. Next generation human skin constructs as advanced tools for drug development. Exp. Biol. Med. 2017, 242, 1657-1668. [CrossRef]

118. Abaci, H.E.; Guo, Z.; Coffman, A.; Gillette, B.; Lee, W.-H.; Sia, S.K.; Christiano, A.M. Human Skin Constructs with Spatially Controlled Vasculature Using Primary and iPSC-Derived Endothelial Cells. Adv. Healthc. Mater. 2016, 5, 1800-1807. [CrossRef]

119. Khiao In, M.; Wallmeyer, L.; Hedtrich, S.; Richardson, K.C.; Plendl, J.; Kaessmeyer, S. The effect of endothelialization on the epidermal differentiation in human three-dimensional skin constructs-A morphological study. Clin. Hemorheol. Microcirc. 2015, 61, 157-174. [CrossRef] [PubMed]

120. Groeber, F.; Engelhardt, L.; Lange, J.; Kurdyn, S.; Schmid, F.F.; Rücker, C.; Mielke, S.; Walles, H.; Hansmann, J. A first vascularized skin equivalent as an alternative to animal experimentation. ALTEX 2016, 33, 415-422. [CrossRef]

121. Koch, L.; Kuhn, S.; Sorg, H.; Gruene, M.; Schlie, S.; Gaebel, R.; Polchow, B.; Reimers, K.; Stoelting, S.; Ma, N.; et al. Laser printing of skin cells and human stem cells. Tissue Eng. Part C Methods 2010, 16, 847-854. [CrossRef]

122. Matai, I.; Kaur, G.; Seyedsalehi, A.; McClinton, A.; Laurencin, C.T. Progress in 3D bioprinting technology for tissue/organ regenerative engineering. Biomaterials 2020, 226, 119536. [CrossRef] [PubMed]

123. Baltazar, T.; Merola, J.; Catarino, C.; Xie, C.B.; Kirkiles-Smith, N.C.; Lee, V.; Hotta, S.; Dai, G.; Xu, X.; Ferreira, F.C.; et al. Three Dimensional Bioprinting of a Vascularized and Perfusable Skin Graft Using Human Keratinocytes, Fibroblasts, Pericytes, and Endothelial Cells. Tissue Eng. Part A 2020, 26, 227-238. [CrossRef]

124. Sharma, D.; Ross, D.; Wang, G.; Jia, W.; Kirkpatrick, S.J.; Zhao, F. Upgrading prevascularization in tissue engineering: A review of strategies for promoting highly organized microvascular network formation. Acta Biomater. 2019, 95, 112-130. [CrossRef] [PubMed]

125. Ponmozhi, J.; Dhinakaran, S.; Varga-Medveczky, Z.; Fónagy, K.; Bors, L.A.; Iván, K.; Erdő, F. Development of Skin-On-A-Chip Platforms for Different Utilizations: Factors to Be Considered. Micromachines 2021, 12, 294. [CrossRef]

126. Biglari, S.; Le, T.Y.L.; Tan, R.P.; Wise, S.G.; Zambon, A.; Codolo, G.; de Bernard, M.; Warkiani, M.; Schindeler, A.; Naficy, S.; et al. Simulating Inflammation in a Wound Microenvironment Using a Dermal Wound-on-a-Chip Model. Adv. Healthc. Mater. 2019, 8, e1801307. [CrossRef]

127. Kwak, B.S.; Jin, S.-P.; Kim, S.J.; Kim, E.J.; Chung, J.H.; Sung, J.H. Microfluidic skin chip with vasculature for recapitulating the immune response of the skin tissue. Biotechnol. Bioeng. 2020, 117, 1853-1863. [CrossRef]

128. Sherratt, J.A.; Dallon, J.C. Theoretical models of wound healing: Past successes and future challenges. Comptes Rendus Biol. 2002, 325, 557-564. [CrossRef]

129. Buganza Tepole, A.; Kuhl, E. Systems-based approaches toward wound healing. Pediatr. Res. 2013, 73, 553-563. [CrossRef]

130. Olsen, L.; Sherratt, J.A.; Maini, P.K.; Arnold, F. A mathematical model for the capillary endothelial cell-extracellular matrix interactions in wound-healing angiogenesis. IMA J. Math. Appl. Med. Biol. 1997, 14, 261-281. [CrossRef] [PubMed]

131. Valero, C.; Javierre, E.; García-Aznar, J.M.; Gómez-Benito, M.J. Numerical modelling of the angiogenesis process in wound contraction. Biomech. Model. Mechanobiol. 2013, 12, 349-360. [CrossRef] [PubMed]

132. Matsuya, K.; Yura, F.; Mada, J.; Kurihara, H.; Tokihiro, T. A Discrete Mathematical Model for Angiogenesis. SIAM J. Appl. Math. 2016, 76, 2243-2259. [CrossRef]

133. Scianna, M.; Bassino, E.; Munaron, L. A cellular Potts model analyzing differentiated cell behavior during in vivo vascularization of a hypoxic tissue. Comput. Biol. Med. 2015, 63, 143-156. [CrossRef] [PubMed]

134. Guerra, A.; Belinha, J.; Jorge, R.N. Modelling skin wound healing angiogenesis: A review. J. Theor. Biol. 2018, 459, 1-17. [CrossRef] [PubMed] 